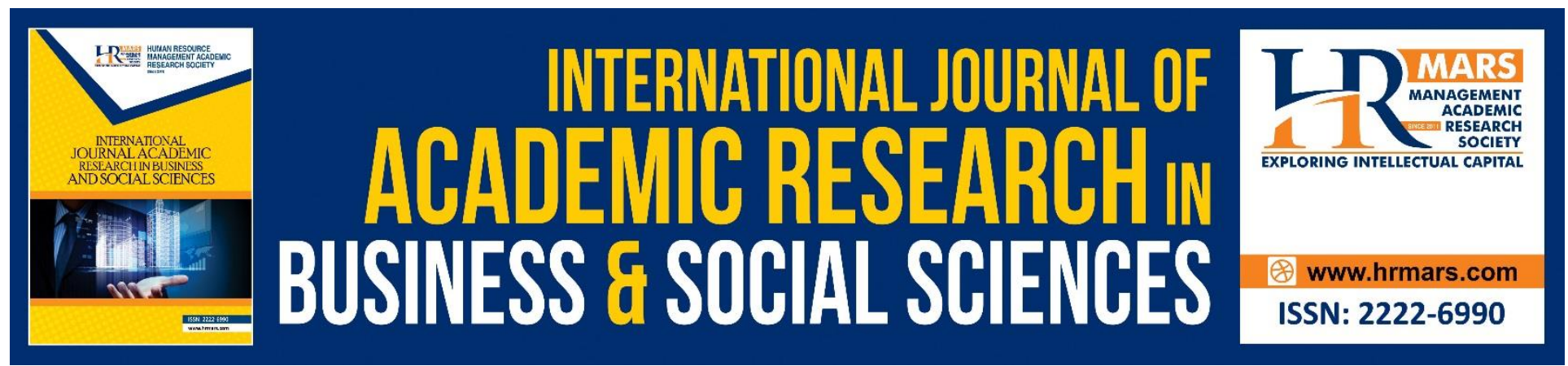

\title{
The Impact of the Use of Internal Audit Standards on Sales in Libyan Economic Institutions: Case Study Al-Ahlia Cement Company
}

Norfadzilah Rashid, Marwan Ibrahim Alfadhli, Noryati Yaakub, Asyraf Afthanorhan, Berhanundin Abdullah

To Link this Article: http://dx.doi.org/10.6007/IJARBSS/v8-i11/5177 DOI: $10.6007 /$ IJARBSS/v8-i11/5177

Received: 03 Nov 2018, Revised: 26 Nov 2018, Accepted: 02 Dec 2018

Published Online: 06 Dec 2018

In-Text Citation: (Rashid, Alfadhli, Yaakub, Afthanorhan, \& Abdullah, 2018)

To Cite this Article: Rashid, N., Alfadhli, M. I., Yaakub, N., Afthanorhan, A., \& Abdullah, B. (2018). The Impact of the Use of Internal Audit Standards on Sales in Libyan Economic Institutions: Case Study Al-Ahlia Cement Company. International Journal of Academic Research in Business and Social Sciences, 8(11), 1356 - 1368.

Copyright: (C) 2018 The Author(s)

Published by Human Resource Management Academic Research Society (www.hrmars.com)

This article is published under the Creative Commons Attribution (CC BY 4.0) license. Anyone may reproduce, distribute, translate and create derivative works of this article (for both commercial and non-commercial purposes), subject to full attribution to the original publication and authors. The full terms of this license may be seen

at: http://creativecommons.org/licences/by/4.0/legalcode

Vol. 8, No. 11, 2018, Pg. $1356-1368$

http://hrmars.com/index.php/pages/detail/IJARBSS

JOURNAL HOMEPAGE

Full Terms \& Conditions of access and use can be found at http://hrmars.com/index.php/pages/detail/publication-ethics 


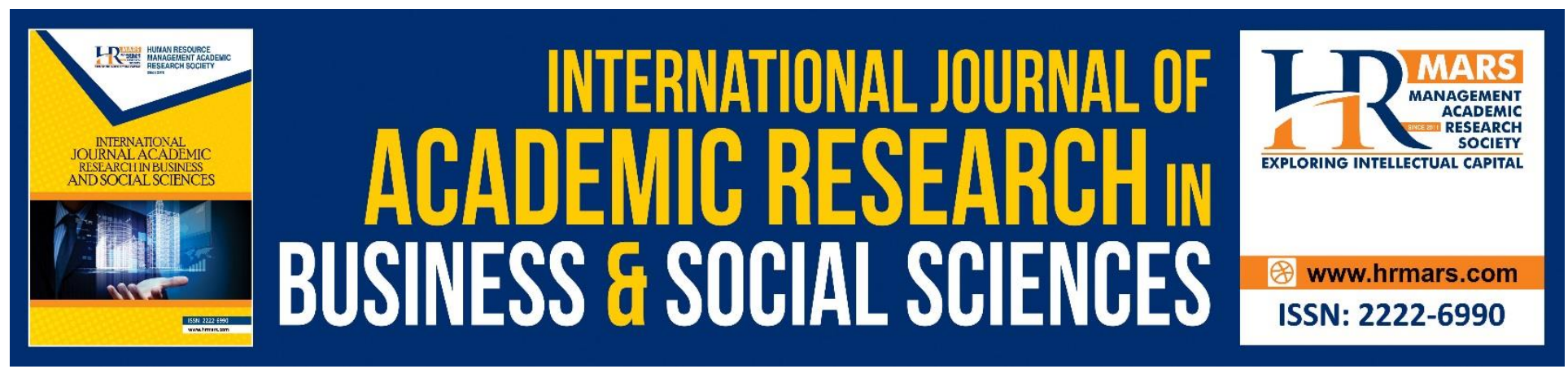

\title{
The Impact of the Use of Internal Audit Standards on Sales in Libyan Economic Institutions: Case Study Al-Ahlia Cement Company
}

\author{
${ }^{1}$ Norfadzilah Rashid, ${ }^{2}$ Marwan Ibrahim Alfadhli, ${ }^{3}$ Noryati Yaakub, \\ ${ }^{4}$ Asyraf Afthanorhan ${ }^{5}$ Berhanundin Abdullah \\ 1,2,3,4 Faculty of Economics and Management Sciences, Universiti Sultan Zainal Abidin, Gong \\ Badak Campus, 21300 Kuala Nerus, Terengganu, Malaysia \\ ${ }^{5}$ Faculty of Islamic Contemporary Studies, Universiti Sultan Zainal Abidin, Gong Badak Campus, \\ 21300 Kuala Nerus, Terengganu, Malaysia \\ Corresponding Author: marwanalfadhli1988@gmail.com
}

\begin{abstract}
The aim of this research was to find out the impact of the internal audit standards on sales in Al Ahlia Cement Company - Libya. The research was based on statistical analysis and descriptive analysis (SPSS). The researchers used both the arithmetic mean for standard deviation to describe the axes of the questionnaire and the Pearson correlation coefficient for the relationship between variables and multiple regression analysis for the Impact of internal audit standards on sales. The study concluded that there is Impact and a strong relationship between internal audit standards and sales in Al-Ahlia Cement Company - Libya, and that internal audit staff have sufficient experience in and adhere to internal audit standards. Auditors are honest and independent in their work. The internal audit has a prominent role in the decision-making process by the beneficiaries, and there is a special section of the sales audit in the institution checks the invoices with the goods and records the sales by an independent person. The researchers recommended that the audit opinion be consistent with accepted accounting principles and internal audit standards. They also recommended analyzing sales regularly to avoid fraudulent bills.
\end{abstract}

Keywords: Internal Audit, Standards, Impact, Sales, Al-Ahlia Cement Company, Libya.

\section{Introduction}

In recent years, companies and institutions in all developed countries have taken an interest in internal audits, One of the reasons for this interest is the separation of departments and ownership, and companies became large-scale (Shara, 2017, pp 245), the internal audit function is concerned with all departments in the company, and is an base reference for management Due 
its recommendations and advice to senior management, where Helping the management to function optimally and ensure the integrity of financial processes (Salehi \& Mayyo, 2016, pp 61), According to the Institute of Internal Auditors, The internal auditor performs broader functions for the external auditor, such as investigating financial matters, detection fraud, etc. (Li, Dai, Gershberg, \& Vasarhelyi, 2018, pp 59-60). Where internal audit standards are reliable and must be relied upon by internal auditors of any institution. These standards are the basis for the work of any internal auditor. Which is an base factor in strengthening the internal audit profession (Abdolmohammadi \& Sarens, 2011, pp 366), whereas Internal audit standards are the rules by which the internal auditor's operations can be evaluated, as compliance with them leads to the achievement of the objectives of this function (Ajila \& Zaqeeb, 2017, pp 63).

As for the Libyan reality, it seems that the situation is very bleak, as the reports issued by the Audit Bureau published recently show the corruption and waste of public money in almost all sectors of the state, This situation shows that it is necessary to attention to the departments of internal auditing in state institutions and increase their efficiency to contribute to reducing such phenomena. In order for internal audit departments to be effective and efficient in their work, it is necessary adopt internal audit standards and abides by them (Karibat, 2017, pp 102).

\section{Research Problem}

The problem in this search that Libya is one of the countries suffering from corruption phenomenon, which has become a widespread epidemic in most Libyan state institutions (Arriqeb \& Mbesout, 2018, pp 57 ), where studies have shown that Libya is a country suffering from financial and administrative corruption because of recent events that happened there, such as the case of the exit on Gaddafi in February 2011, the destruction of state institutions, and there are many bribes due to lack of supervision. Financial and administrative corruption is one of the biggest problems facing the Libyan economy at the moment, and this is a barrier to social and economic development (Massoud \& Sassi, 2016), because of the absence of legal institutions and control in state institutions, which led to the spread of financial and administrative corruption in the country (Malty, 2016).

The audit is currently going through periods of corruption and the possibility that the auditor is a party to the corruption and may be deficient in the performance of his duty in any form (AlFuttaisi, 2014), For lack of control by the authorities, and this leads to embezzlement and manipulation, in particular, If this misappropriation of public money will lead to a decline in the economic situation of institutions and lost their reputation, Moreover, corruption is not the main reason for this research, but the efficiency of the audit and the auditor's compliance with internal auditing standards when it comes to solving problems that occur due to the lack of experience of auditors in institutions.

\section{Research Question}

The research consists of one important question which is:

- Is there a statistically significant effect of Internal Audit Standards (Professional Proficiency, Professional Care, and Scope of Work) on sales in the institution? 


\section{Research Hypothesis}

The research was based on the following hypothesis:

- There is no statistically significant effect of Internal Audit Standards (Professional Proficiency, Professional Care, and Scope of Work) on sales in the institution.

\section{Research Objective}

The main objective of the research is to:

- To examine whether there is a statistically significant effect of Internal Audit Standards (Professional Proficiency, Professional Care, and Scope of Work) on sales in the institution.

\section{Research Importance}

The importance of research is of great importance, as the audit shows the correct and effective result of the institution. Because the goal of any institution is profit and high reputation (Derball, 2012). Sales quantity is the main reason for profit in any institution, The more was audit on sales good and continuous, increase the sales quantity and therefore the increase the profit, Where institutions need to settle accounting data under the development of accounting, and customers also need to know the sales quantity growth of the institution, Therefore, the sales department is the most important section of any profit institution (Hafisa \& Rabeeha, 2015).

\section{Scientific Importance}

The importance of this research shows that it is particularly interested in internal audit standards and its importance in institutions, And the lack of enough studies that included internal audit on sales, Some of them included internal audit and quality of financial statements, internal audit and performance appraisal, profit forecasting and other studies that didn't include sales or internal audit standards. The importance of this research is in the fact that he is concerned about the extent of the auditor's compliance with the internal audit standards in an environment that is without supervision from the organs of power, and the high level of financial and administrative corruption because of the circumstances that the country is undergoing, and apparently, this research talks about Libya, but it basically talks about all the countries that are going through the same conditions, such as Sudan, Tunisia, Syria, Yemen, Iraq, and Egypt. These countries suffer from administrative and financial corruption and the absence of control, because of the periods that occurred there. (Talaat \& Elsayed, 2016; Mohammed \& Abbas, 2016) 


\section{Research variables}

Independent variable

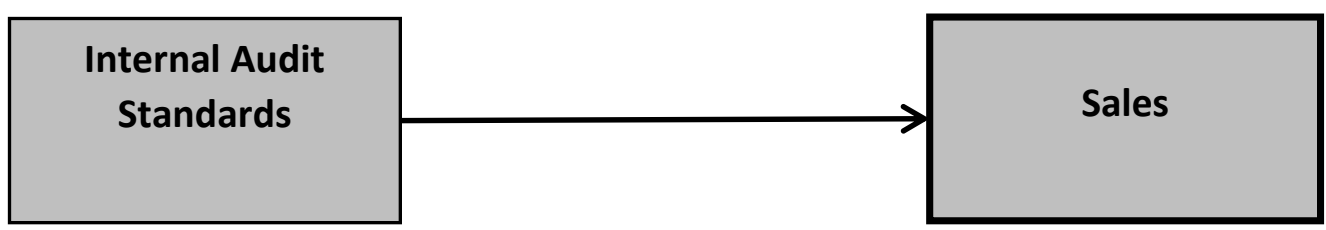

Dependent

variable

\section{Literature Review}

Sari \& Nugroho, (2017) Entitled: The effect of internal audits on sales operations (Case Study at PT. Selamat Lestari Mandiri). The analytical method used is simple linear regression to determine the effect of internal audit on sales. Based on the results of the analysis, there is a significant impact of the internal audit on sales in the company. The implementation of Internal Audit has been carried out properly. This is supported by internal audit indicators including the internal Audit standards: qualifications, objectives and scope of the audit and the authority and responsibility of each auditor.

AbuJbriel (2015) the study aimed to know the independence and professional attention of the internal auditor and impact on the management of profits in the institution, in this study, the researcher analyzed the financial statements of the 33 companies which listed on the Amman Stock Exchange. The researcher used the analytical descriptive approach and quantitative approach because they are aligned with the study objectives. The study found that there is an impact of internal auditing standards on the management of profits in companies in the Amman Stock Exchange.

Ondieki (2013) effect of internal audit on financial performance of commercial banks in Kenya. This study aimed at determining the impact of internal audit on the financial performance of commercial banks in Kenya. Internal audit relied on internal auditing standards, internal skills and controls, and internal control independence. And that this study was conducted by the Ministry of Finance. Quantitative analysis and regression were used as a method of data analysis. Both arithmetic mean and standard deviation were used in data analysis. The results of this study showed that internal audit standards, professionalism, internal control, independence of financial performance in commercial banks, increased internal audit standards, increased audit independence, and increased skills lead to increased financial performance and internal business control. The researchers suggest that management is used in commercial banks as internal audit experience, internal audit independence, and audit standards that help improve financial performance in banks according to actual internal audit practices in Kenya.

Mziane (2012) The objective of this research is to examine the relationship between internal audit in economic institutions in Algeria and internal audit standards, the research was based on 
descriptive and the inferential statistical analysis, to achieve at the results and test the hypotheses. The research found that the internal audit function is in line with the standards of the profession. The research recommended that the staff should be trained in the internal audit departments and that the internal auditor be provided with an appropriate environment for performing his work efficiently.

\section{Research Methodology}

Research methodology is an important rule for any researcher to be able to reach the required results, there are a lot of research methods that the researcher can rely on to reach the objectives of research or study, where each phenomenon is compatible with a specific approach, and also can be used more than one approach in the same research.. Since the researchers have a prior knowledge of everything related to the current research and after reviewing the studies and research conducted on this research, "internal audit standards and its impact on sales" The researchers relied on the SPSS program because it is in line with current research, and through it all the information related to the research problem can be accessed. Researchers used the descriptive approach, such as arithmetic mean and standard deviation. A questionnaire was distributed so that researchers could collect data in order to obtain the best results.

\section{Community and Sample of Study}

The research sample included two departments of the company's factories under the research: Internal Audit and Sales. The sample included 117 employees as follows:

Table (1) the number of employees in each department

\begin{tabular}{|c|c|}
\hline The Department & The Number \\
\hline The Internal Audit & 37 \\
\hline The Sales Department & 80 \\
\hline Total & 117 \\
\hline
\end{tabular}

The researchers relied on (Krejcie \& Morgan, 1970) to choose the sample for the collection of data, and the sample of the Internal Audit Department was 36 employee, Sales Department was 66 employee, were fully recovered by the researchers.

\section{Stability of the questionnaire}

To examine if the paragraphs of the questionnaire are understandable and credible, the researchers relied on Cronbach's alpha to find out the interconnection of paragraphs according to (George \& Mallery ،2003).

In order to verify the validity of the questionnaire for this test, the researcher applied the $\alpha$ Cronbach's equation on the scores of the sample members, and as mentioned by (Isaac \& Michael, 1995), the number of samples between 10 and 30 are useful as follows:

Table (2) $\alpha$-Cronbach stability coefficient

\begin{tabular}{|c|c|c|}
\hline The Department & $\alpha$-Cronbach & Number of Questionnaire \\
\hline
\end{tabular}


INTERNATIONAL JOURNAL OF ACADEMIC RESEARCH IN BUSINESS AND SOCIAL SCIENCES Vol. 8, No. 11, Nov, 2018, E-ISSN: 2222-6990 @ 2018 HRMARS

\begin{tabular}{|c|c|c|}
\hline Internal Audit Standards & .986 & 10 \\
\hline Sales & .879 & 13 \\
\hline
\end{tabular}

The results show that the stability coefficient Of $\alpha$-Cronbach's terms of internal audit Standards amounted to (.986) which is excellent, while the $\alpha$-Cronbach's terms of sales questionnaire was (.879) and it was above good.

Demographic Information of the Respondents

Table (3) illustrate the gender data

\begin{tabular}{|c|c|c|c|c|}
\hline \multirow{2}{*}{ Gender } & \multicolumn{2}{|c|}{ Internal Audit Company } & \multicolumn{2}{c|}{ Sales Department } \\
\cline { 2 - 5 } & Number & Percent & Number & Percent \\
\hline Male & 24 & 66.7 & 41 & 62.1 \\
\hline Female & 12 & 33.3 & 25 & 37.9 \\
\hline Total & $\mathbf{3 6}$ & $\mathbf{1 0 0 . 0}$ & $\mathbf{6 6}$ & $\mathbf{1 0 0 . 0}$ \\
\hline
\end{tabular}

Table (4) illustrates the age data

\begin{tabular}{|c|c|c|c|c|}
\hline \multirow{2}{*}{ The Age } & \multicolumn{2}{|c|}{ Department Internal Audit } & \multicolumn{2}{c|}{ Department Sales } \\
\cline { 2 - 5 } & Number & Ratio & Number & Ratio \\
\hline From 20 to less than 30 & 7 & 19.4 & 21 & 31.8 \\
\hline From 30 to less than 40 & 20 & 55.6 & 31 & 47.0 \\
\hline From 40 to less than 50 & 8 & 22.2 & 9 & 13.6 \\
\hline From 50 and more & 1 & 2.8 & 5 & 7.6 \\
\hline Total & $\mathbf{3 6}$ & $\mathbf{1 0 0 . 0}$ & $\mathbf{6 6}$ & $\mathbf{1 0 0 . 0}$ \\
\hline
\end{tabular}

Table (5) illustrates the division of data of the scientific qualification

\begin{tabular}{|c|c|c|c|c|}
\hline \multirow{2}{*}{ Scientific Qualification } & \multicolumn{2}{|c|}{ Internal Audit Department } & \multicolumn{2}{c|}{ Sales Department } \\
\cline { 2 - 5 } & Number & Ratio & Number & Ratio \\
\hline General Secondary & 2 & 5.6 & 10 & 15.2 \\
\hline Bachelor degree & 23 & 63.9 & 46 & 69.7 \\
\hline Master degree & 10 & 27.8 & 8 & 12.1 \\
\hline PhD & 1 & 2.8 & 2 & 3.0 \\
\hline Total & $\mathbf{3 6}$ & $\mathbf{1 0 0 . 0}$ & $\mathbf{6 6}$ & $\mathbf{1 0 0}$ \\
\hline
\end{tabular}

Table (6) illustrates the division of data on scientific specialization

\begin{tabular}{|c|c|c|c|c|}
\hline Scientific Specialization & \multicolumn{2}{|c|}{ The Internal Audit Dept. } & \multicolumn{2}{c|}{ The Sales Department } \\
\hline & Number & Ratio & Number & Ratio \\
\hline Accounting & 30 & 83.3 & 23 & 34.8 \\
\hline Financing banks & 0 & 0 & 5 & 7.6 \\
\hline Administration & 1 & 2.8 & 17 & 25.8 \\
\hline Economics & 2 & 5.6 & 9 & 13.6 \\
\hline
\end{tabular}


INTERNATIONAL JOURNAL OF ACADEMIC RESEARCH IN BUSINESS AND SOCIAL SCIENCES Vol. 8, No. 11, Nov, 2018, E-ISSN: 2222-6990 @ 2018 HRMARS

\begin{tabular}{|c|c|c|c|c|}
\hline Other & 3 & 8.3 & 12 & 18.2 \\
\hline Total & $\mathbf{3 6}$ & $\mathbf{1 0 0 . 0}$ & $\mathbf{6 6}$ & $\mathbf{1 0 0 . 0}$ \\
\hline
\end{tabular}

Table (7) illustrates the division of the data on job title

\begin{tabular}{|c|c|c|c|c|}
\hline \multirow{2}{*}{ Job title } & \multicolumn{2}{|c|}{ Department Internal Audi } & \multicolumn{2}{c|}{ Sales Department } \\
\cline { 2 - 5 } & Number & Ratio & Number & Ratio \\
\hline $\begin{array}{c}\text { Head of the } \\
\text { department }\end{array}$ & 0 & 0 & 2 & 3.0 \\
\hline Accountant & 13 & 36.1 & 20 & 30.3 \\
\hline Auditor & 17 & 47.2 & 3 & 4.5 \\
\hline Others & 6 & 16.7 & 41 & 62.1 \\
\hline Total & $\mathbf{3 6}$ & $\mathbf{1 0 0 . 0}$ & $\mathbf{6 6}$ & $\mathbf{1 0 0 . 0}$ \\
\hline
\end{tabular}

Table (8) division of data on the period of experience

\begin{tabular}{|c|c|c|c|c|}
\hline \multirow{2}{*}{ The period } & \multicolumn{2}{|c|}{ Internal Audit Department } & \multicolumn{2}{c|}{ Sales Department } \\
\cline { 2 - 5 } & Number & Ratio & Number & Ratio \\
\hline Less than 5 years & 16 & 44.4 & 34 & 51.5 \\
\hline From 5 to 10 years & 12 & 33.3 & 24 & 36.4 \\
\hline From 11 to 15 years & 4 & 11.1 & 4 & 6.1 \\
\hline More than 15 tears & 4 & 11.1 & 4 & 6.1 \\
\hline The total & $\mathbf{3 6}$ & $\mathbf{1 0 0 . 0}$ & $\mathbf{6 6}$ & $\mathbf{1 0 0 . 0}$ \\
\hline
\end{tabular}

Analysis of the Results of the Study, The Hypothesis Test, and the Questionnaire Items

Table (9) results of analysis of the second axis items (Internal Audit Standards)

\begin{tabular}{|l|c|c|c|c|c|}
\hline $\begin{array}{l}\text { The special items of Internal Audit } \\
\text { Standards }\end{array}$ & $\begin{array}{l}\text { Arithmetic } \\
\text { mean }\end{array}$ & $\begin{array}{l}\text { Standard } \\
\text { deviation }\end{array}$ & $\begin{array}{l}\text { Big, } \\
\text { very } \\
\text { big }\end{array}$ & $\begin{array}{l}\text { Little, } \\
\text { very } \\
\text { little }\end{array}$ & Mean \\
\hline $\begin{array}{l}\text { The audit staff has professional } \\
\text { experience and knowledge with the } \\
\text { standards, principles, and tools of } \\
\text { internal audit }\end{array}$ & 4.44 & 0.80868 & 91.6 & 5.6 & 2.8 \\
\hline $\begin{array}{l}\text { Check that the financial auditors have } \\
\text { a knowledge with the standards, } \\
\text { principles, and tools of internal audit }\end{array}$ & 4.36 & 0.68255 & 88.9 & 0 & 11.1 \\
\hline $\begin{array}{l}\text { The internal auditors committed with } \\
\text { the standards of internal audit }\end{array}$ & 3.89 & 0.78478 & 63.9 & 0 & 36.1 \\
\hline
\end{tabular}


INTERNATIONAL JOURNAL OF ACADEMIC RESEARCH IN BUSINESS AND SOCIAL SCIENCES Vol. 8, No. 11, Nov, 2018, E-ISSN: 2222-6990 @ 2018 HRMARS

\begin{tabular}{|l|l|l|l|l|l|}
\hline $\begin{array}{l}\text { The internal auditors committed with } \\
\text { the professional ethics of auditing }\end{array}$ & 3.69 & 1.03701 & 36.6 & 13.9 & 22.2 \\
\hline $\begin{array}{l}\text { There are policies to employ auditors } \\
\text { and adhering with it }\end{array}$ & 3.44 & 1.10698 & 50.0 & 13.9 & 36.1 \\
\hline $\begin{array}{l}\text { Auditors form their views on the basis } \\
\text { of comprehensive fairness in } \\
\text { accordance with accepted accounting } \\
\text { principles }\end{array}$ & 2.53 & 1.25325 & 25.0 & 58.3 & 16.7 \\
\hline $\begin{array}{l}\text { Auditors have appropriate skills to } \\
\text { deal with computer systems }\end{array}$ & 2.75 & 1.64534 & 38.9 & 47.2 & 13.9 \\
\hline $\begin{array}{l}\text { Auditors review the system of the } \\
\text { institution to ensure that it is in line } \\
\text { with the policies and plans the extent } \\
\text { of staff commitment }\end{array}$ & 2.81 & 1.48938 & 30.5 & 47.2 & 22.2 \\
\hline $\begin{array}{l}\text { The audit department manager } \\
\text { examine a sample of work papers } \\
\text { prepared by the auditors }\end{array}$ & 2.33 & 1.17108 & 13.9 & 55.6 & 30.6 \\
\hline $\begin{array}{l}\text { Continuous oversight on the audit } \\
\text { department staff by the manager } \\
\text { regarding their level of professional } \\
\text { performance }\end{array}$ & 3.97 & 0.94070 & 75.0 & 5.6 & 19.4 \\
\hline The total & & $\mathbf{3 . 4 2}$ & $\mathbf{1 . 0 9 1 9 7}$ & $\mathbf{5 4 . 1 3}$ & $\mathbf{2 4 . 7 3}$ \\
\hline
\end{tabular}

Table (10) the results of the analysis of the items of The sales

\begin{tabular}{|l|l|l|l|l|l|}
\hline The items of sales department & $\begin{array}{l}\text { Arithmetic } \\
\text { mean }\end{array}$ & $\begin{array}{l}\text { Standard } \\
\text { deviations }\end{array}$ & $\begin{array}{l}\text { Big, } \\
\text { very } \\
\text { big }\end{array}$ & $\begin{array}{l}\text { Little, } \\
\text { very } \\
\text { little }\end{array}$ & Mean \\
\hline $\begin{array}{l}\text { Check the orders of the customers } \\
\text { and Approval it before send it by } \\
\text { the sales department }\end{array}$ & 4.15 & 0.68483 & 68.4 & 1.5 & 12.1 \\
\hline $\begin{array}{l}\text { Control of outgoing quantities by } \\
\text { an independent person }\end{array}$ & 4.36 & 0.59837 & 93.9 & 0 & 6.1 \\
\hline $\begin{array}{l}\text { The biling department is } \\
\text { independent of each department in } \\
\text { the institution. }\end{array}$ & 4.42 & 0.58337 & 95.5 & 0 & 4.5 \\
\hline $\begin{array}{l}\text { The function is separated: sales, } \\
\text { shipping, financial, accounting }\end{array}$ & 3.94 & 0.83902 & 62.1 & 0 & 37.9 \\
\hline
\end{tabular}


INTERNATIONAL JOURNAL OF ACADEMIC RESEARCH IN BUSINESS AND SOCIAL SCIENCES Vol. 8, No. 11, Nov, 2018, E-ISSN: 2222-6990 @ 2018 HRMARS

\begin{tabular}{|l|l|l|l|l|l|}
\hline $\begin{array}{l}\text { The sales applications which were } \\
\text { not completed should reviewed } \\
\text { periodically }\end{array}$ & 3.44 & 1.06884 & 37.8 & 16.7 & 45.5 \\
\hline $\begin{array}{l}\text { Comparing the shipping documents } \\
\text { with the invoices to assure that the } \\
\text { goods which were shipped has } \\
\text { invoices }\end{array}$ & 2.36 & 1.22332 & 18.2 & 65.2 & 16.7 \\
\hline $\begin{array}{l}\text { Register all the sales invoices in } \\
\text { details in the selling diary. }\end{array}$ & 1.76 & 0.87812 & 4.5 & 84.9 & 10.6 \\
\hline $\begin{array}{l}\text { Keeping a copy of the invoices file, } \\
\text { and analyze the sales regularly }\end{array}$ & 1.83 & 1.01653 & 9.1 & 78.8 & 12.1 \\
\hline $\begin{array}{l}\text { Sales analysis is conducted on a } \\
\text { regular basis. }\end{array}$ & 3.00 & 1.28901 & 39.4 & 33.4 & 27.3 \\
\hline $\begin{array}{l}\text { Comparing the invoices and } \\
\text { accounting registration of the sales }\end{array}$ & 3.53 & 0.86326 & 50.0 & 10.6 & 39.4 \\
\hline The total & $\mathbf{3 . 2 8}$ & $\mathbf{0 . 9 0 4 4 6 7}$ & $\mathbf{4 7 . 8 9}$ & $\mathbf{2 9 . 1 1}$ & $\mathbf{2 1 . 2 2}$ \\
\hline
\end{tabular}

\section{Analysis of Hypothesis Results}

\section{Pearson Correlation}

- There is no statistically significant effect of Internal Audit Standards on sales in the institution.

Table (11) pearson correlation coefficient shows the adoption of Internal Audit Standards and

\begin{tabular}{|c|c|c|c|}
\hline \multicolumn{2}{|l|}{} & Internal Audit Standards & The sales \\
\hline Internal Audit Standards & Pearson Correlation & 1 & $.833^{* *}$ \\
\hline & Sig (2-tailed) & & .003 \\
\hline & The number & 10 & 10 \\
\hline & Pearson Correlation & $.833^{* *}$ & 1 \\
\hline & Sig (2-tailed) & .003 & 10 \\
\hline & The number & 10 & 103 \\
\hline
\end{tabular}

**. Correlation is significant at the 0.01 level (2-tailed).

The table above shows the relationship between: internal audit standards and sales. Where the correlation coefficient was 0.33 . This indicates that the relationship between variables is strong and this result denies the validity of the research hypothesis and ascertains that there is a relationship between the variables. 


\section{Multiple Regression Analysis}

Table (12) multiple Regression Analysis

\begin{tabular}{|c|c|c|c|}
\hline Dependent variables & Coefficients & Prob & Multicollinearity \\
\hline internal audit standard & $0.113^{*}$ & 0.001 & 2.056 \\
\hline C & $9.791^{*}$ & 0.000 & \\
\hline
\end{tabular}

Notes: *, Denotes rejection of the null hypothesis at $1 \%$ significance level.

The previous table shows the regression coefficient of the variables. The regression coefficient for internal audit standards is $\beta \mathbf{0 . 1 1 3}$. This suggests that the increased use of internal auditing standards (professional competence, professional care, scope of work), leads to an increase in sales quantity.

Based on the analysis of the impact of internal audit standards on sales in the company, the use internal audit standards have a positive impact on the sales quantity. Accordingly, compliance with internal audit standards is one of the main reasons for the increase in sales in the institution, and thus the achievement of the institution's objectives and achieves profit.

\section{Results}

i. The use of internal auditing standards in Al-Ahlia Cement Company has an impact on sales and achieve profit,

ii. There is a strong relationship between using internal audit standards and achieving company goals, therefore, increasing sales quantity.

iii. Internal audit standards help to accounts control and provide major assurance to users of financial statements and the report of the internal auditor on its credibility, legitimacy and transparency.

iv. Employees in the Internal Audit Department have professional experience and sufficient knowledge of internal audit standards and are committed to them.

v. Ensure that the internal auditors' knowledge of internal auditing standards.

vi. The internal auditors of the company are committed to the ethics of the profession. And The Company has rules and policies for employ auditors.

vii. Internal auditors may dereliction to express their views in accordance with accounting principles.

viii. Internal auditors have good skills in dealing with computer systems, and Auditors ensure that the institution's system is in line with established policies.

ix. The Director of Internal Audit supervises the work of the auditors in the Company, and moreover, He measures their professional level.

$x$. The Sales Manager examines the purchase invoices before sending them, and sales are supervised by an independent employee. There is in the company an independent billing department.

xi. The function is separated: sales, accounting, Finance, shipping, and sales department reviews purchase orders that are not completed periodically.

xii. Documents and invoices are compared to ensure of existence invoices for Issued sales, and the sales invoices are also recorded in an independent sales record. As sales are regularly analyzed and recorded. 


\section{Recommendations}

i. It is essential to provide information to the users of the financial statements in order to continue the activity of the company, and the need for policies to measure the independence and honesty of the internal auditors.

ii. Auditors should focus on the financial statements to detect errors and, when performing their business must follow the accounting principles.

iii. The importance of following the auditor to the internal audit standards of the company to achieve the objectives set.

iv. The need to support the management of the internal audit department and provide the appropriate environment for auditors to carry out their work independently and impartially.

v. The focus should be on sales analysis step by step, and making the required comparisons between actual sales and issued invoices, and the need focus the independence of the auditor responsible for sales audit.

\section{References}

Abdolmohammadi, M. J., \& Sarens, G. (2011). An Investigation of the Association between Cultural Dimensions and Variations in Perceived Use of and Compliance with Internal Auditing Standards in 19 Countries. International Journal of Accounting, 46(4), 365-389. https://doi.org/10.1016/j.intacc.2011.09.004

AbuJbriel, A. Y. (2015). The Impact of Internal Audit on Earnings Management in the Industrial Companies Listed in Amman Bourse. Master Thesis. Zarqa University.

Ajila, M., \& Zaqeeb, K. (2017). Global Journal of Economic and Business ( GJEB ) Quality requirements of internal audit services, 2(2), 61-73.

Al-Futtaisi, A. G. A. (2014). The financial crisis and the deficiencies in the control of public money in Libya - Analytical study of the reports of the Audit Bureau for the years 20082012. University Journal, 1(16), 189-212.

Arriqeb, S. A. S., \& Mbesout, R. A. (2018). The environment of financial corruption in Libya and its effects. An analytical study for the period (2003-2016). Scientific Afaq: Journal of the Faculty of Graduate Studies, Islamic University of Asmaria, (!), 56-110.

Derball, S. (2012). the behavior of economic institutions in financing their internal growth - A comparative study between the small, medium and large Algerian institutions during the period from 2006 to 2010. University of Qassidi Merabah. Ouargla: Algeria.

Karibat, M. M. (2017). The Extent of Applying International Internal Auditing Standards in Libyan Industrial Companies (Case Study: Cement Al-Ahlya Company). Journal of Afaq lqtishadia, (5), 101-153.

Li, H., Dai, J., Gershberg, T., \& Vasarhelyi, M. A. (2018). Understanding usage and value of audit analytics for internal auditors: An organizational approach. International Journal of Accounting Information Systems, 28(November 2017), 59-76. https://doi.org/10.1016/j.accinf.2017.12.005

Malty, A. F. A. B. S. A.-. (2016). Analytical study of the causes and effects of administrative and 
financial corruption in the Libyan economy. Libyan Affairs, (3), 58-71.

Mohammed, H. J., \& Abbas Salman Mohammed Ali. (2016). The phenomenon of financial and administrative corruption and its role in reducing the performance of the Iraqi economy after 2003. Journal of the Hali Investigator of Legal and Political Sciences., 8(3), 736-777.

Mziane, N. (2012). Internal Auditing Practices in Algerian Public Economic Institutions in Light of Internal Auditing Standards: A Field Study. Journal of Human Sciences, 12(27-28), 187202.

Ondieki, N. M. (2013). Effect of internal audit on financial performance of commercial banks in Kenya.

Sari, Y., \& Nugroho, G. W. (2017). Pengaruh Audit Internal Terhadap Operasi Penjualan. Jurnal IImiah IImu Ekonomi, 5(10), 94-108.

Salehi, Y., \& Mayyo, A. (2016). The reality of internal audit standards application in the Algerian companies (A field study). Journal of the Performance of Algerian Institutions, (9), 61-72.

Shara, A. H. K. (2017). The extent of compliance with the standards of internal international auditing in public shareholding companies in Iraq applied study on a sample of Iraqi banks registered in the Iraqi Stock Exchange. Journal of Graduate Studies- AL- Neelain University, 7(28), 245-272.

Talaat, D., \& Elsayed, B. (2016). Causes of Corruption in the Arab Spring Countries : A CrossNational Comparative Perspective, 8060(July), 1-41. 